\title{
SALVAGE AND UTILIZATION OF WASTE
}

$\mathbf{I}^{\mathrm{T}}$ is of the very essence of war that every resource must be used to resist the advance of the aggressor. There is no room for halfmeasures ; the War is the concern of every one of us; a steadfast purpose, high resolves and a capacity to put those resolves into action should dwell in the hearts and minds of all.

"What can I do to further the ends for which our country is struggling, to keep alight the lamps of freedom of thought and speech ?" is the question on the lips of millions of our fellows. "The work of the armed forces is clear before them; the farmer is providing essential food ; the munitionworkers' contribution is of primary importance. But what can I give to the cause, save by paying taxes, and by carrying on with my own work ?"

Much; and in many directions. An essential and vitally important help which every one of us may give, is summed up in the one word economy. Economy will indeed be forced upon us, for when the British national income at the outbreak of war was reckoned at $\mathfrak{£ 6 , 0 0 0}$ million per annum, the Government was taking from this income

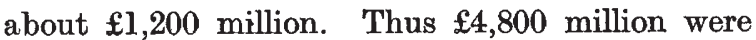
left in the pockets of the people. But if, owing to increased War-time effort, the national income should rise to $£ 7,000$ million, and the annual national expenditure to $\mathfrak{\$ 4 , 0 0 0}$ million, then expenditure by the public must fall to $£ 3,000$ million. There is no gainsaying this. Economize we must, and it is well to begin early.

This, however, is but the passive side of war economy. Waste has a wide meaning, and while it is incumbent on each one of us to practise economy and to avoid waste, we must recognize the fact that there is an active side to the problem and another meaning to the term waste. Waste products of one trade are valuable raw materials for another; waste household products which in peace-time were rightly consigned to the flames, the rubbish heap, or the attic, become, in these days of war, essential parts of the national economy. Their usefulness must not be judged by ordinary economic standards; the national need is the determining factor. So important and pressing is this matter, that a special department of the Ministry of Supply-the Salvage Department-has been set up, which makes the gathering and utilization of such products its special concern.
The figures which deal with the amount of preventable waste are impressive. Thus, before the War, twenty thousand tons of paper and cardboard were thrown weekly into Great Britain's dustbins-well over a million tons a year. Such waste in war-time is almost criminal, and the Salvage Department is to be congratulated on the successful steps which it is taking to diminish this waste. During November last, the tonnage of waste paper collected was 4,500; during April of this year, 9,000 .

There are few things considered less useful than woollen rags. Nevertheless, such rags are used in the manufacture of high-grade paper, and are the raw material of an industry that has flourished in the West Riding of Yorkshire for more than a century. This industry depended in the past on large supplies imported from abroad, and here, as in the paper industry, a substantial increase in the home supply will proportionately reduce the strain on shipping. They who produce, from the recesses of their wardrobes, old and long-discarded clothes, and see that they reach the appropriate distributing agency, will be doing a very real and important service. So also with ferrous (and non-ferrous) metals, all of which take on a new value as potential sources of high-grade steel.

The utilization of animal and vegetable refuse presents most curious and varied technical problems. Some of these problems have been efficiently solved; many others await solution. Most unexpected uses are to be found for various types of such refuse. Banana stalks, for example, of which many tons are available, are a most useful source of fertilizing material, and the household cooked bone has, from this point of view, scarcely any waste. One-eighth of its weight content is fat, one-eighth glue, and the remaining three quarters, properly treated, will appear as feeding meal for cattle, or as bone-fertilizer.

Here, then, is an example of work in which every one of us, townsman or countryman, child or adult, can take part. Such help as a single individual can give may seem a small matter, but in the aggregate the results obtained may be of far-reaching importance. The Salvage Department is doing its work well. In five months the number of town and other councils making returns has risen from 320 to 900 , the populations which these 
councils represent being, in the first instance, 23 millions; in the second, 38 millions. This is a remarkable increase; but it must not be taken to imply that all the councils and local authorities in Great Britain are working at full pressure, or that they have completely developed their methods of attack on the task of the utilization of waste. Different councils have to face different aspects of the problem, and their solution calls for active co-operation between chemist, physicist, biologist and engineer. But the problem of bringing together the waste material is one to which everyone can lend a hand; and the schools can play a specially important part in this task.

Hitherto, the salvaging of waste material has been voluntary, in that local authorities have been asked to provide for the separate collection of material which can be utilized. The Minister of Supply has now announced that all local authorities with populations of more than 10,000 will be required to arrange efficient systems for the collection of salvage, and householders in these areas will be obliged to co-operate. Waste paper and cardboard, scrap metals and household bones are urgent needs, and other materials such as waste food and rags may be added to the list at a later date. The fact that a measure of compulsion is to be introduced need not deter the individual from continuing his own effort, on which, in the long run, will depend the outcome of the official drive for the collection of utilizable waste material.

\section{A PIONEER IN PSYCHOLOGY}

\section{Fsychological Issues}

Selected Papers of Prof. Robert S. Woodworth. With a Bibliography of his Writings. Pp. $x+$ 421. (New York: Columbia University Press; London: Oxford University Press, 1939.) 22s. net.

$\mathrm{W}$

ILLIAM JAMES once declared that psychology was not a science, but only the hope of a science. Much water has flowed under the bridges since that statement was made, and psychology may fairly be said to have proved its claim to recognition, notwithstanding that it is still split up into warring schools or sects. Few men have done so much to bring about the change as R. S. Woodworth, professor of psychology at Columbia University. As a student under James at Harvard, and later on as an assistant to Cattell at Columbia, he came under two powerful influences, which helped to shape his career, and partly explain the breadth of his interest in psychological problems, both on the physiological and on the statistical side. He has recently passed his seventieth birthday, and his colleagues in the department of psychology at Columbia, where he has taught for thirty-six years, have, without his knowledge or consent, prepared this commemorative volume. It was a gracious act, and one which will be warmly approved by many who only know Prof. Woodworth by his writings.

Most students of psychology know him by his "Psychology", a standard work now in its third edition, and by his "Contemporary Schools of
Psychology" (1931), a book which bears the clear impress, not only of its author's ripe learning, but also of his wisdom and his sanity of judgment. Most of Prof. Woodworth's original work, however, consists of contributions to scientific journals spread over a period of more than forty years, with a list of titles covering a dozen octavo pages. This volume comprises some of his most distinctive work, ranging from an early note on the alleged rapidity of dreams (1897) to a paper for the American Journal of Psychology in 1937.

Not the least interesting part of the book is the chapter of autobiography written in 1932 for a comprehensive volume recording the careers of distinguished living psychologists. To an English reader there is one rather odd statement in this chapter. Prof. Woodworth relates that when he began studying psychology in September 1890, James's "Principles" had not yet appeared, and that there was probably no book in existence, at any rate in English, which could be recognized to-day as a text-book in psychology, the nearest approach being Carpenter's "Mental Physiology", a book dating from about 1870. This is surely rather hard on Prof. James Sully, a true man of science, whose "Outlines of Psychology", published in 1884, had completely superseded such books as Carpenter's and Bain's by the time that young Woodworth set out upon what proved to be a career of distinction. Perhaps it has made no difference in the end (who can tell ?); but it must have made a difference at the beginning, that his advisers were not up to date. 